\title{
Specify Other Exons
}

National Cancer Institute

\section{Source}

National Cancer Institute. Specify Other Exons. NCI Thesaurus. Code C159720.

A request to specify the other exons which are not included in the form. 